\title{
Sojurn of Commercial Dispute Redressal Mechanism: Exploratory Description of Commercial Arbitration
}

\author{
Ahtshamuddin Ansari ${ }^{a^{*}}$, Rakesh Kumar Agarwal ${ }^{b}$ \\ a,b Department of Commerce, Meerut College, Meerut (U.P.) India \\ Email id: ahtshamuddinansari@gmail.com
}

\begin{abstract}
Our findings show that in simple and need oriented trade the barter system was the established practice of disposal of the production. The trading disputes were settled amicably by mutual conciliation or by other traders. With the passage of time this system gave way to the exchange of goods by money and thereby the notion of sale and purchase came to the surface with the principle that 'buyer beware'. Disputes, if any, had to be resorted as per usage or custom and by cooperation of other sellers and buyers. By the time this took the form of manufacturing, trading, supplying distributing and navigating to earn profit. The marketing had taken the form of trading and commercial centre giving rise to cartels which also played the role in dispute settlement among traders. From the coal trading to the maritime trading and commerce, commercial arbitration and insurance technique develop. National arbitration and transnational arbitration had been developed along with the domestic and institutional arbitration. To facilitate the uniformity and unification of the arbitration rules and practices came forward to guide the international community. Therefore, the simplification of otherwise complex traditions played key role in smooth growth of dispute resolution to make the trading community tension free. Now the commercial disputes are being settled out of cumbersome adjudicatory process.

Keywords: Commercial arbitration, Sojurn of Commercial Dispute Redressal Mechanism, Negotiation, Mediation, Adjudicatory process.
\end{abstract}

\section{PAPER/ARTICLE INFO RECEIVED ON: 10/07/2019 ACCEPTED ON: 19/09/2019}

Reference to this paper should be made as follows:

Ahtshamuddin Ansari, Rakesh Kumar Agarwal (2019), "Sojurn of Commercial Dispute Redressal Mechanism: Exploratory Description of Commercial Arbitration", Int. J. of Trade and CommerceIIARTC, Vol. 8, No. 2, pp. 289-297 
Sojurn of Commercial Dispute Redressal Mechanism: Exploratory Description of Commercial Arbitration

Ahtshamuddin Ansari, Rakesh Kumar Agarwal

\section{INTRODUCTION}

The participation and help of nonpartisan people in settling the contentions between constituents of human culture, in each circle of human life has ever been available. It might be named as assistance of a center man who appreciates trust of clashing gatherings.

It is referred to in mankind's history as outsider choice and these days it is named as arbitration strategy for settling dispute. In present day times it is viewed as private and effective strategy, all inclusive recognized a technique for settling global business questions. In this types of redressal method parties themselves choose their judge ${ }^{1}$.

This dispute resolution system gives parties an opportunity and forum to settle their disputes through their own desired process. Party autonomy devoid of imposition is key principal of this redressal mechanism²

The ancient society with limited market economy witnessed the facts of stagnation in the sphere of economic growth ${ }^{3}$. Sometimes it was because of the disagreement among the parties in their trading exercises and at some other point, due to the non satisfaction of promise in the agreement. This type of situation gave rise to conflicts, disputes, disorder and anarchy disturbing the peace and tranquility. The eradication of anarchical order makes way for flourishing the trade and commerce; consequently bring prosperity in the society.

\section{REVIEW OF LITERATURE}

This work is not in isolation but linked with the valuable studies and investigation of earlier work done on the topic. The survey of literature on the subject provides an insight to the topic of similar studies. Considerable literature is available on this topic, significant aspect of which has been explored.

Ancient literature on commercial dispute redressal mechanism contained in religious precepts values and resolution modes: Puga, Serni, and Kula. Narad stated Kulani(village council), Serni(Cooperative) and Puga (assemblies). In Islamic literature we found in Quran the concept of Saalis (mediator) to help in resolving problem of disputing parties. These all were destined as adjudicating bodies practicing as arbitral tribunals. In this research paper literature surveyed includes: R.S. Bachawat in his work, Law of Arbitration and Conciliation (2005) examined the different aspects of cultural and jurisprudential aspects of commercial arbitration and conciliation. S.K. Chawla in Law of Arbitration and Conciliation and Practices and Procedure (2004) has observed that the arbitration procedure is new to commercial community in India and explained arbitral way of dispute redressing mechanism. R.A. Sharma presented his thought in "Handbook of Arbitration in Construction Contracts (2005). He focused on the way of settlement of dispute arising out between contracting parties engaged in field of construction. H.C. Johari, Arbitration and Conciliation Act, 1996 gives picture of arbitral tribunals including international commercial arbitration concluded in India and foreign awards. The Journal of Indian Council of Arbitration is published quarterly to provide valuable material on the evolution and development

1 See for detail, A Jayo Govind, "Indian Arbitration System- A critical Appraisal" in N.R. Madhava Menon and B.Debroy,(Eds) Legal Dimensions of Economic Reforms (1975).

2 G. Radhakrisna Rao, "The New Law of Arbitration: A Peripheral Look", Chartered Secretary, July, 2007.

3 See for detail Fali S. Nariman, "Arbitration and ADR in India", a paper presented in conference of International Centre of Alternative Dispute Resolution, New Delhi 1996.

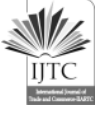


of the commercial arbitration. In this paper, Drahozal "Commercial Norms, Commercial Codes, and International Commercial Arbitration," published in Vanderbilt Journal of Transnational Law (2000) has made endeavours to determine cultural and normative development of International Commercial Arbitration. Dwarka Das Janak, in his paper "A Call for Institutionalized Arbitration in India: A Step towards Certainty Efficiency and Accountability": Supreme Court Cases Journal, 2006 explained at length the necessity and utility of commercial arbitration for settlement of disputes out of court. Subhash Sinha, in his article, "Issues of Arbitrability in International Commercial Arbitration: The present situation 69 (4) published in All India Arbitration Law Reporter 9 (2007) provide information on the critical issues relating to commercial arbitration in India and abroad.

\section{Purpose AND JUSTIFICATION}

The most significant factor in the development of trade and commerce in India and elsewhere was the simple, informal and non-cumbersome system of resolving commercial and contractual conflicts arose among traders. Upon the close of World War-II, a novel trading ethos began to appear giving rise to extended international community. The global growth of trade and commerce saw the birth of new commercial jurisprudence which pertained to non-formal adjudicating machinery. This compelled the trading community to find out new means for settlement of contracting disputes.

\section{ObJeCtives Of THE STUDY}

The arbitration system provides early and non-cumbersome solutions to the commercial and contractual disputes of trading community. The aim of this paper is to find out the extent of utility or futility of commercial arbitration in the light of cultural ethos of trade and commerce and demand of time in the changing commercial circumstances.

\section{HYPOTHESIS}

The medieval and pre-independence commercial system of India has suffered from problems of high costs and delay in the resolution of contractual disputes for slow commercial development. We intended to know whether full potential of commercial arbitration has been realised in India? Is there any correlation between adjudicating mechanism and speedy growth of trade and commerce?

\section{ReSEARCH MeTHOdology}

In the preparation of this research paper, doctrinal method of research is adopted. This study is based on descriptive and comparative method. The researcher endeavours have exploratory in nature.

\section{CHRONICLED ANTECEDENTS OF REDRESSAL NORMS}

Here we will examine the verifiable components liable for the development of commercial arbitration as an effective redressal standard prevailing in the realm of trade and commerce.

\subsection{Resolution of Trade Disputes in Monarchic System}

Under Hindu Law arbitration or mediation as an alternative to dispute resolution by the municipal courts has been prevalent in India since ages ${ }^{4}$. In the Brhadranayaka Upanishad, sage ${ }^{5}$

4 Bachawat R.S., Law of Arbitration and Conciliation,[Nagpur, Wadhwa and Company, 2005].

$$
-291-
$$


Sojurn of Commercial Dispute Redressal Mechanism: Exploratory Description of Commercial Arbitration

Ahtshamuddin Ansari, Rakesh Kumar Agarwal

Yajnavalkya refers to the various types of arbitral bodies like (a) The Puga( a body of Persian belonging to the different sects and tribes but residing in the same locality), (b)The Sreni(an assembly of tradesmen) and artisans belonging to different tribes but connected in some way with each other and (c) The Kula(a group of persons bound by family ties). Such bodies were known as panchayats and their members were known as panchas ${ }^{6}$. Procedures before these bodies were of casual nature, free from the awkward details of the municipal courts.

Moreover, as the members of these bodies were drawn from the same locality and often from the same walk of life as the parties to the dispute, the facts and events could not be concealed from them ${ }^{7}$.

The decisions of these bodies were final and binding on the parties. An aggrieved party could, however, go in appeal against the decision of the Kula to the Sreni; from the decision of the Sreni to the Puga and finally from the decision of Puga to the Pradvivaca. Though these bodies were nongovernmental and the proceedings before them were of informal nature, their decisions were reviewable by the municipal courts 8 .

\subsection{Mode of Salis Under Islamic Socio-Economic Set Up}

During its formation stage Islam provided a system for resolution of family dispute through negotiation, mediation and arbitration. Initially Islamic legal system followed to adopt methods of private settlement for matrimonial discord. It made it incumbent upon the followers to appoint Hakam (neutral middle) man to assist and accommodate the conflicting rights of the disputing parties. That may, safely be called arbitral entity. This system of resolution of conflicts came to India along with the arrival of Arab traders at coastal areas of western India, better known as Kerala. In north-west India it was accompanied with the Middle-East and West-Asian invaders. That was colored in person culture and coined the concept of Saalis-the arbitrator. It is misnomer to call it as a western legal concept. It was known to Indians before the Magna Carta emerged in Europe: The earliest law on arbitration in England was made in $1697 .{ }^{9}$

\subsection{Framework of Redressing Mechanism in British India}

The constant growth of arbitration during the British era was well regulated by various regulations; the legislative history of the notion of arbitration in India began with the regulations made for Bengal, Madras and Bombay by the East India Company. The Bengal regulation of 1772 and 1780 contained the provision on arbitration. Under Regulation of 1781 provision was laid down requiring the judges to prevail upon the parties to submit their disputes to arbitration and the person to act as arbitrator to be mutually agreed upon by the parties. The 1787 regulation included the provision that a person of reputation and integrity must conduct arbitration. Under Bombay Regulation of 1832, it was necessary for the arbitration to be in writing and arbitrator was named. In 1883, the Bengal regulation empowered settlement officer to refer dispute to

5 A.K. Bansal, International Commercial Arbitration: A Study of Jurisdiction by Indian Courts on Foreign Arbitration, Ph.D, Thesis, 2012 Punjab University, Patiala.

Ibid.

Nathuni Lal, Law of Arbitration in India,[Lucknow: Eastern Book Company 1983] p.1-2.

S.D. Singh, Law of Arbitration, [Lucknow : Eastern Book Company, 1980]p.3.

Supra Note 6.

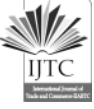


arbitrator ${ }^{10}$.The Code of Civil Procedure of 1859 and 1892 dealt with the working of arbitration with or without the intervention of the court. These measures did not deal with the conflict that was expected to occur in the future. This drawback was removed by the Arbitration Act, 1899. The application of this Act was extended to commercial towns. This journey of arbitration legislation was ended in 1940. Under colonial rule, the important law was enacted in 1940, namely The Arbitration Act, 1940. Under this legislation scattered Indian law on arbitration was consolidated on the lines of the English Arbitration Act, 1934. ${ }^{10}$

\subsection{Modern Concept and Functional Change}

In the western side of the globe development of non-judicial redressal norm had been the offshoot of the Jay Treaty of 1794. John Jay the architect of this treaty incorporated the arbitration provision into the Treaty designed for international justice. The Jay Treaty arbitrations has been treated as the "dawn of contemporary international arbitration"11. "The United States and Great Britain for the first time agreed to use arbitration in their relations with each other when they concluded their first commercial treaty, usually called Jay's Treaty in 1794."12 Another land mark treaty in the field of arbitration is known as "Treaty of Ghent" which was concluded in 1814 between the United States and Britain to redress the grievances of each other arose due to war of 1812. British leaders decided that the matter should be dealt with by an arbitrator and managed to put an end to the slave trade.

In ancient times trade and commerce had transformed Indian economy into trans-national flourishing and sound. One of the key factors responsible for the flourishing of trade and commerce at that time was due to simple and non-cumbersome system of resolving commercial and contractual disputes arose among traders - local as well as foreigners. The practice of deputing panch was widely practiced to decide the dispute. The imperial design of Britons curtailed the liberty and independence of trading community and hindered the expansion of export from India. During British rule, the Indian Arbitration Act, 1940, was enacted. Most part of it regarded Indian trade as a limited adjunct of the British economic system. The law was shaped in the traditional way, with the freedom of the courts to exercise substantial supervision in the course of the arbitration process and with fairly wide powers of court intervention with the arbitration award. A novel trading culture began to appear at the end of World War II. Newly emerging independent nations have given rise to an enlarged global community. The U.N. Charter has highlighted the economic aspects of international life and global interdependence. The global spiral of trade and commerce saw the birth of new concepts of commercial jurisprudence and legal practices ${ }^{13}$. The back logs of contractual and commercial disputes pushed the trading community to find new solution methods for settlement. The perceptions of world over suggested a greater use of alternative system of dispute resolution especially in matters of trade and commerce $^{14}$.

\section{Ibid p.39.}

11 George Schwarzenberger, "Present Day Relevance of the Jay Treaty Arbitrations" Notre Dame Law Review, Issue 4, Volume 53. 715(1978), Available at https://scholarship.law.nd.edu/ndlr/vol53/iss4/3/. Last Visited 25-07-2019.

\section{Ibid.}

Berger, Peter, Klains, International Economic Arbitration, Kluwer Law International 1993.

Idea has been taken from Born Grvy, B. International Commercial Arbitration and Materials, Haugue; Kluwer Law International, 2001. 
Sojurn of Commercial Dispute Redressal Mechanism: Exploratory Description of Commercial Arbitration

Ahtshamuddin Ansari, Rakesh Kumar Agarwal

This method of dispute resolution system was supposed to be less costly, save time, eliminate frustration, and proceed more simply and quickly. These perceptions caused the enactment of the Indian Arbitration Act, 1940. Yet increasing dynamics of market forces and mercantile practices highlighted this enactment's weakness and made it obsolete. There was a need to have an Act "more responsive to contemporary requirement". It was thought that "economic reforms could not be fully effective if the law on the resolution of domestic and international trade disputes remained obsolete. As a result, the Act of 1940 was replaced by the Arbitration and Reconciliation Act, 1996.

The phenomenal growth in our commercial and industrial sector, paves the way for our economy to be opened up to foreign investment in a big way. Today's marketing trends are complex and very competitive that results in commercial disputes involving high stakes. "Unless, there is an efficient mechanism for resolving them speedily and effectively, progress will be retarded".

\subsection{U.N Forwarding Efforts to Evolve Co-Operative Commercial Arbitration}

To consolidate the scattered provisions in transnational legal systems about remedial mechanism of commercial disputes through arbitration United Nations took the lead to unify and prepare model rules and law for the unification and simplification of the law of commercial arbitration. They are called as UNCITRAL Rules and Model Law.

The UNCITRAL rules deal with every sphere of arbitration from the formation of the tribunal to rendering an award. These rules provide the guidelines and flexibility for the smooth operation of arbitral proceedings. At the time when approved, these principles reflected what the drafters believed were the accepted and the ideal autonomous standards for use in international arbitration. In reality these rules represent what actually happens in international arbitration practice and provide a benchmark for review in much arbitration under other framework. The next step came with the formation of the UNCITRAL Model Law of 1985 which attempted at bringing uniform, harmonized and modern commonly accepted norms for international arbitration with three basic features that is party autonomy, limited judicial interference and full judicial support. All the existing modern arbitration laws have now accepted the minimalist approach and the primacy of the principle of party autonomy, as expressed in the Model law.

\section{DifFERENTIAL PARAMETERS OF COMMERCIAL ARbitration}

In pre industrial era most of the trade and commercial transactions work carried through navigations. When the business community was engaged in finding new sea routes for transnational trade it evolved the concept of merchant navy. With the establishment of sea industries, growth and commerce and intention of world powers to end "anarchical" international system. Pacific means have been adopted to maintain orderly system of trade through sea resulting in the emergence of the concept of maritime arbitration. It attained the notion of trans national maritime arbitration. Shipping industry, salient component of commerce promoted and preferred arbitration as a way of resolving disputes relating to evaluation of damage to transported goods and ensuring liability attached to the carrier; damages to the ship caused by nature of carried goods; demurrage, issues pertaining to the non execution of the charter party; sale; construction and ship repairs and maritime insurance. Important feature of 
maritime arbitration is that it is an offspring of commercial arbitration and is a creature of contract.

The nature of trade transaction contributed in the development of ad Hoc arbitration seeking easy and informal solution of petty differences. The emergence of ad hoc arbitration owed to this tendency. Ad hoc arbitration refers to "arbitration" in which arbitration is performed by the parties and the arbitral tribunal in compliance with procedures decided by the parties or, in the absence of agreement, defined by the arbitral tribunal at a preliminary meeting after the arbitration proceedings has begun. 'ad hoc arbitration' is therefore agreed upon and negotiated by the parties without any reference to an arbitral body. Such arbitration takes place in accordance with the procedure provided under the national Acts and the rules framed under them. "ad hoc arbitration" can be arbitration for domestic or international trade.

In a complex commercial world of large scale production and constant supply of production need the skills of trained and qualified arbitration. They prefer the service of the institutions in the area of arbitration. 'Institutional arbitration ' is an arbitration conducted by an arbitral institution, a body that makes special provisions for arbitration purposes. The parties ${ }^{15}$ may stipulate, in the arbitration agreement, to refer an arbitrable dispute between them, for resolution to a particular institution of national or international character. Institutional arbitration is one in which a specific permanent character organization intervenes and performs the duties of assisting and conducting the arbitral process, as provided by that institution's laws. It is pertinent to note that these institutions do not arbitrate the dispute, it is the arbitrators who arbitrate, and so the term arbitration institution is inappropriate and only the rules of the institution apply. ${ }^{16}$

In commercial world trade usages and customs have been preferred over the formal legal norms. But where any legislation make provision for arbitration for the settlement of contractual dispute it become incumbent to have resort to the statutory provisions. When arbitration is performed in accordance with the provisions of a special act, which expressly provides for arbitration in respect of disputes arising on issues covered by that act, it is referred to as statutory arbitration. Statutory Arbitration is such a proceeding where the parties are referred to the arbitrator in terms of the provision made in a particular statute. There are a number of national and state laws that provide for such arbitration.

The arbitration process and procedure is often governed by native customs for national statutes to deal with indigenous commercial dispute it is racked as domestic arbitration. The expression "Domestic Arbitration" has not been defined in the Act of 1996, though it finds place in the Part I of the Act. ${ }^{17}$ ' Domestic Commercial Arbitration ' means an arbitration relating to disputes arising from legal relations, either contractual or non-contractual, in accordance with the law in force in India and where parties are (a) persons who are Indian nationals; or (b) a corporate body incorporated in India; or (c) any entity or agency of the Government of India and/or State

15 Anurag K. Agarwal, "Party Autonomy in Commercial Arbitration", Journal of Indian Council of Arbitration, Vol. XI, No.3, Oct-Dec. 2006

16 Dato Cecil Abraham, "Importance of Institutional Arbitration in International Commercial Arbitration", Journal of Indian Council of Arbitration, Vol. XLI, No.4 Jan-March, 2007.

17 O.P. Malhotra, The Law and Practice of Arbitration and Conciliation (Lexis Nexis Butterworths, New Delhi, 2006). 
Sojurn of Commercial Dispute Redressal Mechanism: Exploratory Description of Commercial Arbitration

Ahtshamuddin Ansari, Rakesh Kumar Agarwal

Government and/or the local bodies including local authorities, State Government and Union Territories; or (d) an association or body of individuals and/or a partnership firm having its place of business in India.

In case the dispute arises in one country and arbitration sit in another country, in accordance with usage and customs of trade of that another country, it is termed as foreign arbitration. The arbitration taking place in one country is another state's foreign arbitration. It does not matter whether the arbitration is commercial or non-commercial or whether the parties are from the same country, from different countries or that one or all are from same State. Since even a domestic arbitration in one State is a foreign arbitration in another State. In some legal systems the courts will not come to the aid of a "foreign" arbitration by way of aiding in the procurement of evidence, granting interim orders of protection or the like. However, many modern arbitration laws provide that the courts will aid arbitrations taking place in a foreign State. ${ }^{18}$

Though we are especially concerned with evolution, working and utility of commercial arbitration it is within our interest to know the comparative view of formal structure of non commercial arbitration and commercial arbitration. Arbitration may be used to resolve social and financial conflicts in the society. It particularly derive strength from commercial contracts with a provision to refer the disputes, if any, to a person of integrity and reputation who is impartial. Lord Mustill averred "commercial arbitration must have existed since the dawn of commerce. All traders potentially evolve disputes, and successful trader must have a means of dispute resolution other than force".$^{19}$

\section{CONCLUSION}

The sojurn of commercial arbitration lies in its structure by which parties are regarded "as arbitration masters." This is created through the choice of contracting parties. It focuses exclusively on getting the traders back to justice. Its formation ultimately results in unification of traders community free rivalry venom. The cultural values of the socio-economic order tend to work for individuals and institutions "to resolve feuds rather than ongoing conflicts." Commercial arbitration notion and process "could well infuse the spirit of brotherhood between contentious traders" and contracting parties. By adopting the way of arbitration a dispute is to be resolved "amicably together rather than as a combat to be won". The traders feel that "no one is victorious or vanquished" and that enmity disappears. Recourse to arbitral proceedings keeps alive and maintains trust and respect between traders. It is a matter of commercial experience of traders that dispute may arise during performance of mercantile transactions and business contracts. But efforts are being made to preserve the gap with controllable boundaries. Absence of reasonable care to avoid conflict may result in "profitable transactions resulting in a likely loss." That's why entrepreneurs and traders have developed and explored the forum for friendly dispute settlement that may occur during business transactions.

18 For example, Spain, Arbitration Act 2003, provides in its articles1(2) and 23 that the courts will enforce interim orders of protection ordered by the arbitral tribunal even when the tribunal has its seat outside Spain

19 Michael J Mustill, Arbitration: History and Background, Journal of International Arbitration, No. 6, 1989, p.43.

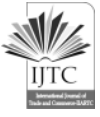




\section{REFERENCES}

[1]. Bachawat, R.S. (2005). Law of Arbitration and Conciliation, Wadhawa and Company, Nagpur.

[2]. Bansal, A.K. (2012). International Commercial Arbitration : A Study of Jurisdiction by Indian Courts on Foreign Arbitration, Ph.D. Thesis, Punjab University, Patiala.

[3]. Berger Peter Klains (1993). International Economic Arbitration, Kluwer Law International.

[4]. Lal, Nathuni (1983). Law of Arbitration in India, Eastern Book Company, Lucknow.

[5]. Radha Krishan Roa, G. (2007). The New Law of Arbitration : A Peripheral Look, Chartered Secretary, July.

[6]. Singh. S.D. (1980). Law of Arbitration, Eastern Book Company, Lucknow. 